\title{
The Comparison of Muscle Protein Turnover Rate among the Egg Type, Meat Type and Japanese Native Chicken Stocks
}

\author{
Yoshizane Maeda, Shin Okamoto, Kaoru Okano* \\ Takeshi Tomita ${ }^{* *}$ and Tsutomu HashiguchI \\ Department of Animal Science, Faculty of Agriculture, \\ Kagoshima University, Kagoshima-shi 890 \\ * University Farm of Faculty of Agriculture, Kyushu \\ University, Kasuya-machi, Fukuoka-ken 811-24 \\ ** Department of Animal Science, School of Agriculture, \\ Nagoya University, Chikusa-ku, Nagoya-shi 464-01
}

(Received November 16, 1989)

\begin{abstract}
The fractional rates (\%/day) of synthesis (Ks) and degradation (Kd) of muscle protein, at 4 weeks of age, of the egg type stock (two strains of White Leghorn), meat type stock (two kinds of commercial broiler) and Japanese native stock (four breeds of Japanese native breeds) of chicken were determined by measuring the output of $\mathrm{N}^{\tau}$-methylhistidine $\left(\mathrm{N}^{\tau}-\mathrm{MH}\right)$ in their excreta. The fractional rates of synthesis of muscle protein for the egg type tock, meat type stock and Japanese native stocks were $6.2-6.8 \%$ I day, $7.3-8.9 \% /$ day and $8.8-12.6 \% /$ day, respectively. The fractional rates of degradation of these stocks were 4.6-5.1\%/day, 2.8-3.0\%/day and 6.1-7.7\%/day, respectively. The Japanese native stock showed higher rates of both synthesis and degradation of muscle protein. The $\mathrm{Kd}$ values for Japanese native stock were about 1.2-1.7 times higher than those for the egg type, and 2.0-2.8 times higher than thorse for meat type stock. The $\mathrm{Ks} / \mathrm{Kd}$ values in egg type, meat type and Japanese native stocks were calculated as $1.22-1.48,2.61-2.97$ and 1.40-1.68, respectively. The accumulation efficiency of muscle protein, (Ks-Kd) $/ \mathrm{Ks}$, at 4 weeks of age was calculated as $17.7-32.4 \%$ in the egg type stock, $61.6-66.3 \%$ in the meat type stock and $28.8-40.5 \%$ in the Japanese native stock.

These results suggest that 1) the muscle protein turnover rate differs between egg type, meat type and native stocks, and 2) the improvements for body size, growth rate and/or feed efficiency caused changes in muscle protein turnover rate, in the relative value $(\mathrm{Ks} / \mathrm{Kd})$ of protein synthesis to degradation and in the accumulation efficiency (Ks-Kd)/ $\mathrm{Ks}$ of muscle protein.
\end{abstract}

Jpn. J. Zootch. Sci.,61 (8): 701-706, 1990

Key words : muscle, protein turnover, chicken, differenciation, improvement

The accumulation of muscle protein is determined by the fractional rates of synthesis and degradation of muscle protein ${ }^{11}$. Rates of synthesis and degradation of muscle protein are usually measured using specific radioactivity or urinary $\mathrm{N}^{\tau}$-methylhistidine $\left(\mathrm{N}^{\tau}-\mathrm{MH}\right)$. $\mathrm{N}^{2}-\mathrm{MH}$ is a component of actin in all muscle and of myosin in white muscle, and approximately $90 \%$ of $\mathrm{N}^{\tau}-\mathrm{MH}$ is located in skeletal muscle ${ }^{2,3}$. $\mathrm{N}^{\tau}-\mathrm{MH}$ from muscle protein cannot be reutilized for protein synthesis and is rapidly and quantitatively excreted in the urine after its release by degradation ${ }^{4}$. ASATOOR and ARMSTRONG ${ }^{5)}$ proposed that the rate of 
degradation of muscle protein could be estimated by measuring the urinary excretion of $\mathrm{N}^{2}-\mathrm{MH}$. By measuring the urinary excretion of $\mathrm{N}^{\tau}-\mathrm{MH}$, the muscle protein turnover rate has been studied in $\operatorname{rats}^{3,6,7)}$, humans ${ }^{8,9)}$, cattle $^{10-12)}$, chicken $^{13-15)}$ and Japanese quail ${ }^{16-19)}$.

The muscle protein turnover rate is associated with the growth rate. The chicken is a typical animal having a variety of body sizes. By selective breeding for body size, egg production and/or feed utilization, many breeds and strains with various characteristics have been developed. Chickens are thus able to be classified into egg type stock, meat type stock and native stocks. These stocks have different growth rates and body sizes.

In the present study, the authors examined the fractional rates of synthesis $(\mathrm{Ks})$ and degradation $(\mathrm{Kd})$ of muscle protein and the characteristics of muscle protein turnover rate in egg type, meat type and native chicken stocks.

\section{Materials and Methods}

Egg type stocks (two Strains of White Leghorn), meat type stocks (two kinds of commercial broiler) and Japanese native stocks

Table 1. Standard values of body weight(gr.) of male at 4 weeks of age and adult in each stock

\begin{tabular}{lcc}
\hline \multicolumn{1}{c}{ Stock } & 4 Weeks of Age & Adult \\
\hline Egg type & & \\
White Leghorn (E1) ${ }^{11}$ & 250 & 2200 \\
White Leghorn (E2) & 250 & 2300 \\
Meat type & & \\
Commercial broiler (M1) & 880 & $4500<21$ \\
Commercial broiler (M2) & 850 & $4500<21$ \\
Japanese native chicken & & \\
Gifujidori & 110 & 1300 \\
Tokarajidori & 190 & 2200 \\
Tokuchijidori & 80 & 900 \\
Katsura Chabo & 90 & 750 \\
Goishi Chabo & 100 & 750 \\
\hline 1) E1 : Shaver & & \\
E2 : Dekalb & & \\
M1 : Hubbard & & \\
M2: Cobb & & \\
2) Parent stock &
\end{tabular}

(Gifujidori, Tokarajidori, Tokuchijdori, and 2 kinds of Chabo ; Japanes Bantum) were used in this study. The standard values of body weight for adult native chickens are shown in Table 1. All chickens were reared in an electric brooder from hatching to 2 weeks of age, and were then housed in wire-floored individual cages that were artificially lighted for $14 \mathrm{hrs}$ per day and maintained at $22^{\circ} \mathrm{C}$. The feed consisted of a Kagoshima University formula which contained $19 \%$ crude protein and 13.1 $\mathrm{MJ} / \mathrm{kg}$ metabolizable energy. Both water and feed were available ad libitum. The feed intake was individually measured by the use of feeder cups $^{20)}$.

Complete 24-hr excreta collections were individually obtained for 4 days at 4 weeks of age. Each sample was stored at $-40^{\circ} \mathrm{C}$ until analyzed for $\mathrm{N}^{\tau}$-methylhistidine $\left(\mathrm{N}^{\tau}-\mathrm{MH}\right)$. The quantitative analysis of $\mathrm{N}^{t}-\mathrm{MH}$ was conducted via the methods described by Nishizawa et al. ${ }^{21)}$. Each excreta sample was hydrolyzed with $80 \mathrm{ml}$ of $6 \mathrm{~N}-\mathrm{HCl}$ at $110^{\circ} \mathrm{C}$ for 24 hrs to convert acetyl $\mathrm{N}^{\tau}-\mathrm{MH}$ to $\mathrm{N}^{\tau}-\mathrm{MH}$. After filtration of the hydrolyzed sample, the filtrates were reduced to dryness and redissolved in distilled water. This procedure of drying and redissolving was repeated eight times. The dried hydrolysate was dissolved in $10 \mathrm{~m} l$ of $0.2 \mathrm{M}$ pyridine and $4 \mathrm{ml}$ of the dissolved hydrolyzate applied to a Dowex $50-X$ 4 column (pyridine form 200-400 mesh). After the acidic and neutral amino acids were eluted with $200 \mathrm{~m} l 0.2 \mathrm{M}$ pyridine, $\mathrm{N}^{\tau}-\mathrm{MH}$ was eluted with $100 \mathrm{ml} 1 \mathrm{M}$ pyridine ${ }^{21)}$. The $\mathrm{N}^{2}-\mathrm{MH}$ assay was conducted via the methods described by WARD ${ }^{22)}$.

The fractional rates of degradation and synthesis of muscle protein were calculated based on the daily amount of $\mathrm{N}^{\tau}-\mathrm{MH}$ excretion ${ }^{13)}$. In order to calculate accurately the fractional rates of synthesis and degradation for myofibrillar protein, it is necessary to estimate the pool size (P) of $\mathrm{N}^{\tau}-\mathrm{MH}$ in the whole body skeletal muscle and the amount of 


\section{Muscle Protein Turnover Rate of Various Chicken Stocks}

$\mathrm{N}^{2}-\mathrm{MH}$ originating from the degradation of skeletal muscle. The pool size (P) of $\mathrm{N}^{\tau}-\mathrm{MH}$ in the whole body skeletal muscle was calculated by the equation in the previous report ${ }^{13)}$.

Fractional rates of degradation (Kd) and synthesis (Ks) of the muscle protein in each bird were calculated by FUNABIKI et al. ${ }^{23)}$. The accumulation efficiency of muscle protein was calculated via the equation of $(\mathrm{Ks}-\mathrm{Kd}) / \mathrm{Ks}$ that was proposed by FunABIKI ${ }^{24)}$. Data were analyzed by a one-way analysis of variance. The statistical significance of differences among means was evaluated via Duncan's multiplerange tet.

\section{Results}

The fractional rates of synthesis and degradation of muscle protein in the egg type stock, meat type stock and native chicken stocks at 4 weeks of age are given in Table 2. The means of the fractional rate of synthesis (Ks) of muscle protein at 4 weeks of age of the egg type stock, meat type stock and native stocks were $6.2-6.8 \%$ /day, $7.3-8.9 \% /$ day and $8.8-14.2$ $\% /$ day, respectively. The $\mathrm{Ks}$ values for the egg type and meat type stocks, which are improved breeds, were statistically lower $(\mathrm{P}<$ 0.05) than those of native stocks except Chabo
(Japanese bantam). The $\mathrm{Ks}$ values for muscle protein in the meat type stocks were slightly higher than those in the egg types. The difference in $\mathrm{Ks}$ value between the egg type and meat type was significant in $\mathrm{M}_{1}$ for commercial broilers, but not significant in $\mathrm{M}_{2}$. In the native stock, the Ks values for Chabo were smaller than those for other native breeds except Tokuchijidori.

The fractional rates of degradation $(\mathrm{Kd})$ at 4 weeks of age for the egg type stock, meat type stook and native stocks were $4.6-5.1 \%$ / day, $2.8-3.0 \% /$ day and $6.1-9.6 \% /$ day, respectively. The $\mathrm{Kd}$ values for native stock were about 1.2-1.7 times higher than those for the egg type stock and 2.0-2.8 times higher than those for the meat type stock. The Kd values for meat type stocks were almost half those for the egg type stock. In the native stock, the $\mathrm{Kd}$ values for the Chabo (6.1-6.4\%/day) were smaller than those for other breeds (7.3$9.6 \% /$ day). Both $\mathrm{Ks}$ and $\mathrm{Kd}$ values in native stock were higher than those in egg type and meat type stocks. The relative values of $\mathrm{Ks}$ to $\mathrm{Kd},(\mathrm{Ks} / \mathrm{Kd})$, in the egg type, meat type and native stocks were calculated as 1.22-1.47, $2.61-2.96$ and $1.40-1.68$, respectively. The values for the commercial broiler were rela-

Table 2. Fractional rate of synthesis and degradation of muscle protein at 4 weeks of age in the various chicken stocks

\begin{tabular}{|c|c|c|c|c|c|}
\hline Stocks & $\begin{array}{l}\text { No. of } \\
\text { birds }\end{array}$ & $\underset{(\mathscr{O} / \mathrm{day})}{\mathrm{Ks}}$ & $\begin{array}{c}\mathrm{Kd} \\
(\mathscr{g} / \mathrm{d} a y)\end{array}$ & $\mathrm{Ks} / \mathrm{Kd}$ & $\frac{(\mathrm{Ks}-\mathrm{Kd}) / \mathrm{Ks}}{(96)}$ \\
\hline & & Mean $\pm \mathrm{SD}$ & Mean $\pm S D$ & & \\
\hline \multicolumn{6}{|l|}{ Egg type } \\
\hline White Leghorn (E1)" & 5 & $6.9 \pm 1.0^{*}$ & $4.6 \pm 0.7^{b e}$ & 1.47 & 32.4 \\
\hline White Leghorn (E2) & 8 & $6.2 \pm 0.9^{a}$ & $5.1 \pm 0.6^{\mathrm{cd}}$ & 1.22 & 17.7 \\
\hline \multicolumn{6}{|l|}{ Meat type } \\
\hline Commercial broiler (M1) & 8 & $8.9 \pm 1.1^{\circ}$ & $3.0 \pm 0.8^{a}$ & 2.96 & 66.3 \\
\hline Commercial broiler (M2) & 5 & $7.3 \pm 0.9^{b a}$ & $2.8 \pm 0.5^{\mathrm{a}}$ & 2.61 & 61.6 \\
\hline \multicolumn{6}{|l|}{ Japanese native chicken } \\
\hline Gifujidori & 8 & $12.6 \pm 1.6^{\mathrm{d}}$ & $7.5 \pm 0.7^{8^{\mathrm{h}}}$ & 1.68 & 40.5 \\
\hline Tokarajidori & 6 & $11.1 \pm 1.8^{\mathrm{d}}$ & $7.3 \pm 1.0^{\prime g ~ h}$ & 1.52 & 34.2 \\
\hline Tokuchijidori & 4 & $10.9 \pm 1.9^{d c}$ & $7.7 \pm 1.0^{n}$ & 1.42 & 29.3 \\
\hline Chabo (N1) & 6 & $8.8 \pm 1.2^{b}$ & $6.1 \pm 0.9^{d e}$ & 1.44 & 30.6 \\
\hline Chabo (N2) & 7 & $9.0 \pm 1.5^{b c}$ & $6.4 \pm 1.0^{\mathrm{ei}}$ & 1.40 & 28.8 \\
\hline
\end{tabular}

"E1:Shaver E2: Dekalb M1: Hubberd M2:Cobb N1: Katsura Chabo N2: Goishi Chabo

* Column values with the same superscript are not statistically significant $(P<0.05)$ 
tively higher (2.61-2.96) than those for egg type and Japanese native stocks. The values for the Japanese native stock were slightly higher than for the egg type stock.

The accumulation efficiency of muscle protein can be evaluated from the equation of (Ks$\mathrm{Kd}) / \mathrm{Ks}$ suggested by FunABIKI ${ }^{24)}$. The values for the egg type, meat type and Japanese native stocks were calculated as $17.7-32.4 \%$, $61.6-66.3 \%$ and $28.8-40.5 \%$, respectively. The high values $(\mathrm{Ks}-\mathrm{Kd}) / \mathrm{Ks}$ for the commercial broiler reflect the high growth rate in broilers.

\section{Discussion}

The muscle protein turnover rate of chicken has been estimated from the excretion of the $\mathrm{N}^{\tau}-\mathrm{MH}$, in normal and dystrophic strains ${ }^{25,26)}$, via variation among chicken stock ${ }^{12,13)}$, and via the effect of the $d w$ gene ${ }^{27)}$. In order to use $\mathrm{N}^{\tau}-\mathrm{MH}$ excretion in urine as a measurement of muscle protein breakdown, it is necessary to demonstrate that (1) the $\mathrm{N}^{\mathrm{t}}-\mathrm{MH}$ in muscle protein cannot be reutilized or protein synthesised and is rapidly and quantitatively excreted in the urine after it is released by degradation of myofibllar protein and that (2) skeletal muscle is the major source of urnary $\mathrm{N}^{\tau}$-MH. SAUNDERSON and LEsLie ${ }^{28)}$ demonstrated that urinary excretion is valid for estimating the muscle protein degradation rate in chicken because of quantitative recovery of $\mathrm{N}^{\tau}-\mathrm{MH}$ within 1 week except for turkey. However, HARRIS et al. ${ }^{29)}$ reported that excretion of $\mathrm{N}^{\tau}-\mathrm{MH}$ by 4 to 18 -week-old cockerels cannot be used as a reliable index of muscle protein breakdown in vivo, because recovery of radioactivity in excreta were incomplete and progressively decreased with increasing age. In his data, the recovery of radioactivity during the first 4 days showed almost $85 \%$ at 4 weeks of age. Although recovery at 4 weeks of age is not $100 \%$, we considered that excretion of $\mathrm{N}^{\tau}-\mathrm{MH}$ at 4 weeks of age is not entirely invalid for a relative comparison of muscle protein degradation rate among various chicken stocks.

It is well known that muscle protein turnover rate is associated with growth rate ${ }^{16,30)}$. MAEDA at al. ${ }^{16)}$ demonstrated that the growth rate correlates highly with the muscle protein turnover rate. In this study, the muscle protein turnover rates at 4 weeks of age differed between the chicken stocks. Both Ks and $K d$ values for Japanese native stock were higher than those for meat type and egg type stocks. The meat type stock showed a higher Ks and a lower Kd than the egg type stock. It was recognized that the improvement in economical traits caused the changes in both $\mathrm{Ks}$ and $\mathrm{Kd}$ to adapt to economic performance.

In previous reports, HAYASHI et al. ${ }^{14)}$ and MAEDA et al. ${ }^{13,25)}$ measured the muscle protein turnover rates of White Leghorn, commercial broilers, White Plymouth Rock, Satsuma native fowl (one kind of Japanese native fowl) and Fayoumi. Although the muscle protein turnover rates for egg type stock and Japanese native stock in the present study are similar to the results of the previous report ${ }^{13)}$, the $\mathrm{Ks}$ for commercial broilers (7.3-8.9\%/day) in the present study is lower than that in the previous report (11.1-12.6\%/day). HAYASHI et al. ${ }^{14)}$ measured the muscle protein turnover rate of layers and broilers at 3,6 and 9 weeks of age. From his data, if we calculate the muscle protein turnover rate at 4 weeks of age in proportion to age, we can expect that $\mathrm{Ks}$ and $\mathrm{Kd}$ values in layers are $10.4 \%$ /day and $5.6 \%$ / day, respectively, while those values in broilers are $8.6 \% /$ day and $4.3 \% /$ day, respectively. The $\mathrm{Ks}$ value in layer and $\mathrm{Kd}$ value in broilers were higher than the corresponding rates in the present study.

MAEDA et al. ${ }^{13,25)}$ demonstrated the $\mathrm{Ks}$ and $\mathrm{Kd}$ values for muscle protein in Satsuma native fowl (Satsumadori) were $13.9 \%$ /day and $8.6 \%$ / day, respectively, and that those in Fayoumi were $13.0 \% /$ day and $10.1 \%$ /day, respectively. The muscle protein turnover rates for Satsuma native fowl and Fayoumi are similar to the 


\section{Muscle Protein Turnover Rate of Various Chicken Stocks}

turnover rates for the Japanese native chicken stock breeds listed in Table 2.

Both $\mathrm{Ks}$ and $\mathrm{Kd}$ values in the Japanese native chicken stock were high compared to the egg type and meat type stocks. Most Japanese native fowls were not selected for any economic characteristics such as body weight, feed efficiency or egg production. Therefore native chickens are slow in growth rate and small in body weight compared to improved chickens. Skeletal muscle in the body is the major protein deposit of an animals body and has the function of controlling movement as well as preserving protein and providing amino acids in protein metabolism. Therefore high muscle protein turnover rates in the native chicken may be associated with their growth rate and body weight. If there is an association between muscle protein metabolic rate and fitness, a high metabolic rate at an early age is probably advantageous for survival. It is likely that jungle fowl in habitats in the jungle of Southeast Asia have a high metabolic rate of muscle protein.

The differences between stocks in muscle protein turnover rate were shown also in the genetically diverse quail lines selected for body size $^{16)}$. The $\mathrm{Ks}$ and $\mathrm{Kd}$ values ware significantly different among three lines of quail selected for body size at 6 weeks of age, the fractionnal rate of synthesis of the line selected for large body size (LL line: $13.2 \% /$ day) was higher than that of the non-selected line (RR line: $11.5 \% /$ day), whereas the line selected for small body size (SS line : 8.1\%/day) was lower than that of the RR line. The fractional rates of degradation, at 3 weeks of age, for both the LL line (4.1\%/day) and the SS line (5.6\%/day) were lowr than that of $\mathrm{RR}$ line (7.0\%/day). The muscle protein turnover rate tendencies of the three quail lines selected for body size were similar to those of the egg type, meat type and Japanese native chicken stocks.

Both $\mathrm{Ks} / \mathrm{Kd}$ values and $(\mathrm{Ks}-\mathrm{Kd}) / \mathrm{Ks}$ values were low in the egg type stock and high in the meal type stock. Those values for native stock were slightly higher than those for egg type stock.

In conclusion, both $\mathrm{Ks}$ and $\mathrm{Kd}$ values in native stock were higher than those of the egg and meat type stocks (improved breeds). The meat type stock with high growth rate demonstrated relatively high $\mathrm{Ks}$ value and low Kd value compared to the egg type stock. These results suggest that genetic improvements in body size, growth rate and/or feed utilization caused a change in muscle protein turnover rate.

\section{Acknowledgment}

Author wish to express their thanks to Dr. K. Hayashi, Departmrent of Animal Science, Faculty of Agriculture, Kagoshima University, for his technical advice, and to Ms. Mary Fitzgerald, Board of Education of Ijuin-cho, Kagoshima Prefecture, for her reading of the manuscript.

\section{References}

1) Millwaed, D.J., P.J. Garlick, D.O. Nnanyelgo and J.C. WATERLOW, Biochem. J., 156 : 185-188. 1976.

2) Haverderg, L.N., P.T. Omsted, H.N. Munro and V.R. Young, Biochim. Biophys. Acta., 405: 67-71. 1975.

3) Nishizawa, N., M. Shimbo, S. Hareyama and R. Funabiki, Br, J. Nutr., $37:$ 345-353. 1977.

4) Cowglll, R.W. and B. FreEbukG, Arch. Biophys., $71: 466-472.1957$.

5) Asatoor, A.M. and M.D. Armstrong, Biochem. Biophys. Res. Commun., 26 : 168-174. 1967.

6) Nishizawa, N., R. Funabiki and S. Hareyama, J. Nutr. Sci. Vitaminol, 21 : 383-385. 1975.

7) Young, V.R., S,D. Alexis, B.S., BAliga, H.N. Munro and W. Muecke, J. Biol. Chem., 247: 35923600. 1972.

8) Long, C.L., L.N., Haverberg, V.R., Young, J.M. KINNY, H.N. MUNRo and J.W. GEIGER, Metabolism, $24: 929-935.1975$.

9) Murry, A.J., Ballerd, F.J. and F.M. Tomas, Anal. Biochem., $116: 537-544.1981$.

10) HAR.RIS, C.I and G. MiLne, Br. J. Nutr., 45 : 411422. 1981.

11) McCarthy, F.D., W.G., Bergen and D.R. HaWkins, J. Nurt., $113:$ 2455-2463. 1983.

12) Nishizawa, N., Y. TOYOda, T. Noguchi, $S$. Hareyama, H. Itabashl and R. Funabiki, Br. J. 


\title{
Maeda, Okamoto, Okano, Tomita and Hashiguchi
}

Nutr., $42: 247-252.1979$.

13) Maeda, Y., K. Hayashi, S. Toyohara and T. Hashiguchi, Biochem. Genet., $22: 687-700.1984$.

14) Hayashi, K., Y. Tomita, Y. MaEda, Y. Shinagawa, K. INOUE and T. HASHIzUME, Br. J. Nutr., $54: 157^{-}$ 163. 1985.

15) Jones, S.J., E.D. Aberle and M.D. Judge, Poultry Sci., 65 : 2142-2147. 1986.

16) Maeda, Y., K. Hayashi, T. Hashiguchi and $S$. OКамото, Biochem. Genet, 24 : 207-216. 1986.

17) Maeda, Y., K. Sato, S. OKamoto and T. HASHIGUCHI, Biochem. Genet., 26 : 395-399. 1988.

18) Maeda, Y., N. Yamanovchi, S. Okamoto and $T$. HAS HIGUChI, Jpn. J. Zootech. Sci., 60 : 484-490. 1989.

19) MaEda, $Y$., M. FuJn, $S$. OKamoto and $T$. HASHIGUCHI, Biochem Genet., 27 : 603-611. 1989.

20) Maeda, Y., H. Kawasaki and T. Hashiguchi, Jpn. J. Zootech. Sci., $53: 388-394.1982$.

21) Nishizawa, N., T. Noguchi, S. Hareyama and R. Funabiki, Br. J. Nutr., $38: 149-151.1977$.
22) W ARD, L.C., Anal. Biochem., $88: 598$ 604. 1978.

23) Funabiki, R., Y. Watanabe, N. Nishizawa and $S$. Hafe Yama, Biochim. Biophys. Act, 451: 143-150. 1976.

24) FUNABIKI, R., SEIKAGAKU., $58: 1150-1156.1986$.

25) Maeda, Y., K. Hayashi, M. Mizutani and T. Hashiguchi, Poultry Sci., $66: 757-759.1987$.

26) Hillgartnor, F.B., A.S. Williams, A. Flanders, D. MORIN and R.J. HANSEN, Biochem. J., 196 : 591601. 1981 .

27) Makda, Y., S. Matsuoka, N. Furuichi, K. Hayashi and T. HASHIGUChi, Biochem. Genet., $25: 253-258$. 1987.

28) Saunderson, C.L. and S. Leslie, Br. J. Nutr, 50 : 691-700. 1983.

29) Harris, C.I., G. Mine and R. MCDiarmid, Br. J. Nutr., $57:$ 467-478. 1987.

30) Martin, R.J., Animal Growth Regulation (Campion, D.R., G.J. Hausman and R.J. Martin, eds.) 183-210. Plenum Publishing Corporation. New York., 1989

\section{卵用鶏，肉用鷄および日本在来鶏における筋肉蛋白質 代謝回転速度の比較}

\author{
前田芳實 • 風本 新 ・岡野 香**富田 武** ・橋口 勉 \\ 鹿児島大学農学部，鹿児島市 890 \\ * 九州大学農学部付属農場, 福岡県粕屋町 811-24 \\ **名古屋大学農学部, 名古屋市千種区 464
}

\begin{abstract}
本研究では卵用種，肉用種および日本在来種のニワトリについて，4 週橉時における筋肉蛋白質代謝 回転速度の分析を行なった．筋肉蛋白質代謝回転速度は蕒尿中の $\mathrm{N}^{\tau}-\mathrm{MH}$ の排泄量より推定した．卵 用種，肉用種および在来種の筋肉蛋白質の合成速度 (Ks) はそれぞれ 6.2-6.8\%/day，7.3-8.9\%/ day 怙よび 8. 8-12.6\%/day；また分解速度 (Kd) はそれぞれ 4.6-5.1\%/day，2.8-3.0\%/day およ び 6.1-7.7\%/day と評価された，また，在来鷄は一般に合成速度および分解速度共に高い值を示す傾 向にあり，Kd は卵用種および肉用種の約 2 倍の值を示した． $\mathrm{Ks} / \mathrm{Kd}$ 值は卵用種，肉用種および在来 種において，それぞれ 1.22-1.48，2.61-2.97 および 1.40-1.68 と評価された. 筋肉蛋白質の蓄積效率 と考えられる $(\mathrm{Ks}-\mathrm{Kd}) / \mathrm{K}_{\mathrm{s}}$ は卵用種，肉用種捛よび在来種でそれぞれ 17.7-32.4\%，61.6-66.3\% 朽 よび 28. 8-40.5\% と計算され，ブロイラーは他の彩種に比較して蓄積効率が高いことが示された．筋肉 蛋白質代謝回転速度のこれらの鶏種間のちがいは，それぞれの䊿種の産肉性や飼料利用性の実態をよく 反映している。
\end{abstract}

